\title{
THE INFLUENCE OF BRAND AWARENESS AND E-SERVICE QUALITY ON CONSUMER PURCHASING DECISIONS IN BOOKING HOTEL ROOMS ON TRAVELOKA
}

\author{
Ria Oktavia, Agung Permana Budi, dan Febianti. \\ Sekolah Tinggi Perhotelan Bali Internasional. \\ riaoktava1911@yahoo.com
}

\begin{abstract}
This study was to determine the effect of brand awareness and e-service quality on consumer purchasing decisions in booking hotel rooms in traveloka. The subject of this study amounted to 100 random people who had booked a hotel room through the Traveloka website. The results of the questionnaire were analyzed using multiple linear regression to see the effect between variable brand awareness, eservice quality and purchasing decisions. The results of this study indicate that brand awareness and e-service quality have a significant effect of $67.1 \%$ on the variables of consumer purchasing decisions in hotel room bookings, on the traveloka website. The implication of this research is to see the contribution of the variables studied to be used as consumer decisions in making purchases on room sales services on the website, so marketing is important to know.
\end{abstract}

Keyword: Brand Awareness, E-Service Quality, Consumer Decision Making

\section{BACKGROUND}

The internet is one of the electronic devices that are widely used for communication, research, transaction, entertainment, and other activities. Along with the increasing number of internet users, this also has a positive impact on companies or businesses that use internet facilities. One of them is the internet used to develop its business online. The internet is used as a media to market and conduct business promotions at a cost that is affordable and covers all walks of life.

Travel agents also take advantage of this opportunity by opening sales and services online or familiarly heard as an online travel agent (OTA). With the OTA it makes it easy for consumers to book hotel rooms without any space and time restrictions. Through the OTA products from hotels are sold through the website or mobile application owned by each OTA. So that the hotel can expand its business by selling online by collaborating with OTA services help hotels in marketing and sales, increasing hotel revenue.

One of the OTAs currently widely used by the community is Traveloka OTA. Traveloka is one of the famous flight ticket and hotel search sites in Southeast Asia, based on interviews conducted by the swa.co.id website (2018), Traveloka.com was only established in October 2012, but currently Traveloka.com has partnered with 
more from 70 domestic and international airlines that reach more than 100,000 routes in Asia, Europe and America. Traveloka also has more than 100,000 hotels in Southeast Asia and several other countries in Asia and Europe. This is all to provide a better travel experience for customers who order online.

Traveloka presents online service quality or better known as E-service quality. Traveloka provides consumers with a variety of convenience with a fast ticket booking and hotel reservation system, easy and safe payment, providing a variety of ticket prices and hotels so that consumers can choose according to budget and desire.

In addition to the quality of service provided in deciding to make a purchase, a consumer will first evaluate and select brands that are known and not infrequently consumers buy a product just because the brand is well known to consumers. To get to know a product other than a brand, and to provide or even improve brand function, it is necessary to instill brand awareness or brand presence in consumer memory, with the aim of differentiating one product from another product or competitor's products.

Based on the analysis carried out by DailySocial.id (2015) Traveloka is one of the sites with brand awareness and the highest top of the mind compared to similar online sites that provide airplane ticket, train and hotel reservation services and whereas Tiket.com and pegipegi.com the plunger first still occupies a position under Traveloka. It shows that Traveloka managed to defeat its competitors and do the right marketing method through its promotions which are almost in various media.

Based on the above, the problem statement from the writing of this paper is to see and to know the influence of the role of brand awareness and e-service quality on consumer decisions in booking hotel rooms on traveloka websites both simultaneously and partially.

\section{THEORY}

\section{Brand Awareness}

Durianto (2004: 54) states that, brand awareness is the ability of a prospective buyer to recognize and remember the brand as part of one product with the brand involved. According to Aaker (2009: 39), brand awareness is the ability of a prospective buyer to recognize or remember return that a brand is part of a particular product category.

The brand awareness pyramid from low to highest level is as followsAaker (1997) in Suprapti (2015):

1. Unaware brands (not aware of the brand) are the lowest level in the brand awareness pyramid where consumers are not aware of a brand.

2. Brand Recognition (brand recognition) is a minimum level of brand awareness, where the introduction of a brand appears again after the recall is done through aided recall.

3. Brand Recall (remembrance of the brand) is the recall of the brand without assistance (unaided recall). 
4. Top of Mind is the brand that is first mentioned by consumers or which first appears in the minds of consumers, or that brand is the main brand of various brands that are in the mind of a consumer.

\section{E-Service Quality}

E-service quality is defined as a meeting between consumer expectations without direct interaction in the services provided by Pearson $(2012 ; 201)$. According to Santosa (2013) e-service quality can be interpreted by the overall evaluation of customers regarding the excellent quality of electronic services provided to customers in the online market.

Dimensions of E-service quality according to Bernardo (2013; 344):

1. Efficiency (efficiency)

a) Site makes it easy for consumers to find what consumers need.

b) Site allows consumers to complete transactions quickly.

c) The information presented on the website is displayed in full.

d) Consumers can easily log in to the website quickly.

e) Website pages load quickly.

2. System availability

a) This site is always available for business.

b) This site has no errors when used.

3. Fulfillment

a) This site makes items available for delivery within the appropriate time period.

b) The site provides honest promises for the offer given.

c) This site allows changes to reservations and cancellations.

d) There are promotions available on this site.

4. Privacy (privacy)

a) Consumers feel that consumer privacy is protected on this site.

b) Consumers feel safe transacting with this site.

\section{Buying Decision}

According to Kotler (2015), purchasing decisions are actions of consumers to want to buy or not to the product. Of the various factors that influence consumers in purchasing a product or service, consumers usually always consider the quality, price and products that are known to the public. According to Setiadi (2010) buying behavior implies that individual activities are directly involved in exchanging money with goods and services and in the decision-making process that determines these activities. Consumer decisions to buy a product always involve physical activity (in the form of direct consumer activities through the stages of the purchasing decision process) and mental activities (ie when consumers value products according to certain criteria set by individuals). Before consumers decide to buy, usually consumers go through several stages first, namely, (1) problem recognition, (2) information search. (3) evaluation of alternatives, (4) decision to buy or not, (5) post-purchase behavior. Another understanding of purchasing decisions according to Schiffman and Kanuk (2013: 437). 


\section{RESEARCH METHODOLOGY Sample and Population}

In this study the population used as a sample is the user of Traveloka online travel agent in Bali who has already booked a hotel room. The sampling technique used in this study was random sampling using sampling techniques with the formula Wibisono in Riduwan and Kuncoro (2013: 255) $\mathrm{n}=\mathrm{z} / 2$ : $\mathrm{e} 2=(1,96 X 0.25): 0.052$ $=96.04100$ the number of samples used in this study amounted to 100 respondents.

\section{Operational Variable}

The variables in the final study of the dependent and unbound variables. The dependent variable consists of Brand Awareness (X1) and E-service Quality (X2), while the unbound variable is the Purchasing Decision (Y)

\section{Data collection technique}

The data generated in this study are qualitative data that are quantified, it needs to be changed into a score, that is by giving a score as follows:
a) Answers are given a score of 5 with the category strongly agree.
b) Answers are given a score of 4 with the agree category.
c) Answers are given a score of 3 with the category quite agree.
d) Answers are given a score of 2 with disagree categories.
e) Answers are given a score of 1 with the category strongly disagree

\section{Data Analysis Techniques}

This study uses multiple regression analysis to predict how far the influence of independent variables on dependent variables. The tool used as a data analysis instrument is the IBM SPSS 17. The steps taken are, Validity and Reliability Test, and do Descriptive Analysis, including the description: a. Frequency of respondent data. b. Frequency of respondent's answer to brand awareness variable (X1) c. Frequency of respondent's answer to the Quality variable e-service (X2) d. Frequency of respondent's answer to the Purchase Decision variable (Y). Next, multiple linear regression analysis is done by testing the regression equation. After that, the Classic Assumption Test consists of: Normality Test, Multicollinearity Test, Heteroscedasticity Test, Auto Test Correlation and Analysis of Correlation Coefficient (R) In general, there are three types of relationships in the correlation coefficient analysis after the Simultaneous Significance Test (F Test) is carried out.

\section{ANALYSIS AND DISCUSSION \\ Test Partial Hypothesis (t Test)}

The results of the $t$ test between brand awareness variables, e-service quality and purchasing decisions for Traveloka's online travel agents in Bali are as follows 


\section{Test Result t}

\begin{tabular}{|l|c|c|c|c|}
\hline \multicolumn{1}{|c|}{ Independent Variable } & Koefisien & $\mathrm{t}$ & Sig. & Keterangan \\
\hline (Constant) & 13,480 & 6.940 & 0.000 & Signifikan \\
\hline Brand awareness $\left(X_{1}\right)$ & 0.223 & 2.142 & 0.035 & Signifikan \\
\hline Kualitas E-service $\left(X_{2}\right)$ & 0.460 & 4.869 & 0.000 & Signifikan \\
\hline
\end{tabular}

Showing that in the partial test ( $\mathrm{t}$ test), the brand awareness variable has a $\mathrm{t}$ count value of 2.142> t table (1.98) and sig of $0.035<0.05$, the brand awareness variable gives a significant influence on the purchase decision variable. Then for the e-service quality variable has a value of t count of 4.869> $\mathrm{t}$ table (1.98) and sig of $0,000<0.05$, the e-service quality variable has a significant influence on the variable purchasing decisions.

Based on simultaneous and partial testing, the regression model formed is

With :

$$
Y=13,480+0,223 X_{1}+0,460 X_{2}+e
$$

$$
\begin{aligned}
& \mathrm{Y}=\text { Purchase Decision, } \\
& \mathrm{X}_{1}=\text { brand awareness, } \\
& \mathrm{X}_{2}=e \text {-service Quality. }
\end{aligned}
$$

\section{Simultaneous Influence Hypothesis Test (Test F)}

To find out the simultaneous effect of independent variables on the bound variable used the $\mathrm{F}$ test. With the provisions if $\mathrm{F}$ count $>\mathrm{F}$ table and significance value $<0.05(\alpha=5 \%)$, the independent variables simultaneously have a significant effect on the dependent variable.

The $\mathrm{F}$ test results between brand awareness variables, e-service quality and purchasing decisions for Traveloka's online travel agents in Bali are as follows.

\section{Result Test F}

\begin{tabular}{|l|c|c|c|c|c|}
\hline \multicolumn{1}{|c|}{ Model } & $\begin{array}{c}\text { Sum of } \\
\text { Squares }\end{array}$ & Df & $\begin{array}{c}\text { Mean } \\
\text { Square }\end{array}$ & F & Sig. \\
\hline Regression & 1275.662 & 2 & 637.831 & 98.723 & 0.000 \\
Residual & 626.698 & 97 & 6.461 & & \\
Total & 1902.360 & 99 & & & \\
\hline
\end{tabular}

Indicates that in the simultaneous test (Test F), the calculated $F$ value is 98.723> F table (3.09) and sig. amounting to $0,000<0,05$ so that it failed to reject $\mathrm{H} 0$ which means the brand awareness variable, the quality of e-service simultaneously (simultaneous) has a significant influence on the purchase decision variable on Traveloka's online travel agent in Bali.

\section{Determination Coefficient Value (R-Square)}

The following is the value of the coefficient of determination (R-Square) resulting from the regression analysis. 
Determination Coefficient Value (R-Square)

\begin{tabular}{|c|c|c|}
\hline $\mathrm{R}$ & $\mathrm{R}-$ Square & Adjusted $R$ Square \\
\hline 0.819 & 0.671 & 0.664 \\
\hline
\end{tabular}

Showing the determination coefficient value (R-Square) obtained is 0.671 , means that the diversity of consumer purchasing decisions of Traveloka online travel agents in Bali can be explained by brand awareness, e-service quality of $67.1 \%$ and the remaining $32.9 \%$ is influenced by other variables besides the variables used in the regression model. Meanwhile, the value of $\mathrm{R}$ shows the magnitude of the relationship between brand awareness, e-service quality and purchasing decisions are quite strong because the value is 0.819 is close to 1 .

\section{CONCLUSION}

From the results of multiple linear regression, the equation $\mathrm{Y}=13.480+$ $0.223(\mathrm{X} 1)+0.460(\mathrm{X} 2)+\mathrm{e}$ is obtained, if brand awareness and e-service quality are high, the purchasing decision is also high. And Based on the test of the coefficient of determination (R2) brand awareness variable and e-service quality has an effect of $67.1 \%$ on the variables of consumer purchasing decisions in hotel room bookings, while the remaining $32.9 \%$ are external influences not examined in this study.

\section{SUGGESTION}

Advertising media can be done through digital media which is popularly used by people such as Facebook, YouTube, Instagram, etc. In addition, it can use offline media as an alternative to increase brand awareness. and also must anticipate system damage that might occur at any time. Guarantee the web and the application runs well so it does not disappoint consumers who are currently accessing it. Improve security in dealing with debit and credit cards without being troublesome. Consumers can easily and conveniently transact with debit or credit cards without fear of security problems

\section{REFERENCE}

Aaker, D. A. 2009. Managing brand equity.Simon and Schuster.Aaker, David A. Managing brand equity.Simon and Schuster, 2009.

Bernardo, M., Marimon, F., dan Del Mar Alonso-Almeida, M. (2012).Functional Quality And Hedonic Quality: A Study Of The Dimensions Of E-Service Quality In Online Travel Agencies. Information \& Management, 49(7-8), 342-347.

Durianto, Darmadi, Sugiarto, dan Budiman, Lie Joko. 2004. Brand Equity Ten, Strategi Memimpin Pasar. Jakarta. PT. Gramedia Pustaka Utama.

dailysocial.id, Available
2015. at:
Dailysocial.id. https://dailysocial.id/post/traveloka-populer-survei- 
$\underline{\text { nusaresearch }}$

[Akses 20 Maret 2018].

Kartajaya, Hermawan. 2014. Think New ASEAN! Rethinking Marketing Towards ASEAN Economic Community. PT. Gramedia Pustaka Utama. Jakarta.

Kotler, Philip, 2015. Manajemen Pemasaran : Analisis, Perencanaan, Implementasi dan Pengendalian Jilid 1, Edisi Terjemahan. Jakarta: Erlangga.

Riduwan dan Kuncoro, Ahmad. 2013. Cara Menggunakan Dan Memakai Analisis Jalur (Path Analisis).Bandung: CV Alfabeta.

Schiffman, Leon G. \& Leslie L. Kanuk. 2013. Consumer Behavior: Tenth Edition. New Jersey. Prentice-Hall Inc.

Setiadi, Nugroho J. 2010. Perilaku Konsumen. Jakarta: Kencana.

Sugiyono, 2015. Metode Penilitian Manajement. Bandung: CV. Alfabeta.

Suprapti,Lilik. 2015. Analisis Pengaruh Brand Awareness, Perceived Value, Organizational Association Dan Perceived Quality Terhadap Keputusan Pembelian Konsumen.Skripsi. Magister Manajemen. Universitas Dipenegoro Semarang.

SWA.CO.ID, 2017. SWA. [Online] Available at: https://swa.co.id/swa/trends/marketing/traveloka-layani-7-juta$\underline{\text { konsumen }}$

[Akses 2 Agustus 2018]

Pearson,Ann,S,T.\& Chris,Friffin. 2012. The Role Of E-Service Quality And Informatin Quality In Creating Perceived Value; Antecedebts To Web Site Loyalty. Information Systems Management, Taylor \& Francis Group

Traveloka.com, 2018. blog.traveloka.com. [Online] Available at: https://blog.traveloka.com/en/travel-guides-and-tips/ [Akses 19 Mei 2018] 